\title{
Uterine Agenesis
}

National Cancer Institute

\section{Source}

National Cancer Institute. Uterine Agenesis. NCI Thesaurus. Code $C 99103$.

A cong enital abnormality characterized by the complete absence of the uterus. 